MATEUSZ PALIGA

ANITA POLLAK

BARBARA KOŻUSZNIK

University of Silesia in Katowice

\title{
TACTICS OF INFLUENCE AND DEINFLUENTIZATION, PERSONALITY AND THE PERSONAL SENSE OF POWER AMONG POLISH MANAGERS
}

\begin{abstract}
Power in organizations creates interpersonal settings and lays the ground for designating individual roles and positions of superiors and subordinates. In such a context, influence tactics are situationspecific behaviors used to change the behavior of others and achieve organizational goals. The notion that power and influence can be based on personal or positional variables was used to design the framework of the present studies intended to describe how trait- and state-like variables are related to influence tactics and deinfluentization. The subjects were 250 Polish managers. Study $1(n=250)$ was undertaken to collect data about the influence tactics of Polish managers to fill the void in information in the field of social psychology in organizations. In Study $2(n=104)$ we correlated influence tactics with the personal sense of power. The results proved that the perception of having the ability to exert power over others was positively related to rational persuasion, apprising, and pressure. In Study $3(n=69)$ we investigated the relationships of influence tactics and deinfluentization with the Big Five and directiveness. The results showed that Neuroticism was positively correlated with pressure, legitimating, and coalition, but negatively with rational persuasion and consultation. Extraversion was positively correlated with rational persuasion, so was Conscientiousness. Agreeableness was negatively related to coalition. Directiveness was in a positive relation with pressure but correlated negatively with personal appeals. Deinfluentization positively correlated with Agreeableness and negatively with directiveness.
\end{abstract}

Keywords: influence tactics; deinfluentization; personal sense of power; the Big Five; directiveness.

Correspondence concerning this article can be sent to Mateusz PAliga, PhD, Institute of Psychology, Faculty of Social Sciences, University of Silesia, ul. Grażyńskiego 53, 40-126 Katowice, Poland; e-mail: mateusz.paliga@us.edu.pl; ORCID: https://orcid.org/0000-0002-8538874X; ANITA POLLAK, ORCID: https://orcid.org/0000-0002-9921-6607; BARBARA KożUSZNIK, ORCID: https://orcid.org/0000-0002-0574-8742. 


\section{THEORETICAL BACKGROUND}

\section{Social Power and Influence}

The possession of power and influence have long been recognized as essential for managerial work (Gonçalves, 2013; Yuk1, 2010) and success (Chemers, 2000). Although power and influence are different phenomena (Faeth, 2004; Porter et al., 2003), a definite distinction between them is troublesome, but essential, because it creates a bridge between the power approach and behavior approach to leadership (Yukl, 2010). Interpersonal influence is a process of social influence in which an individual can expect support from others in the accomplishment of a common task (Chemers, 2000; Yukl, 2010). Power in an organization is construed as a managerial resource (Singh, 2009) or a reservoir of force (Porter et al., 2003) that refers to the control over other important resources, such as information or decision-making premises. In organizational circumstances, power often stems from held positions (Anderson et al., 2012; Magee \& Galinsky, 2008; Overbeck \& Park, 2001). Thibaut and Kelly (1959) noted that such control could be exercised to obtain resources necessary precisely to exert influence. Many authors (Boughton, 2011; Faeth, 2004; Porter et al., 2003; Turner, 2005) view power as the potential to influence others, while influence as the actual ability to apply and exercise it.

Power is based on positional (Bennett, 1988) or personal variables (Anderson et al., 2008; French \& Raven, 1959). Positional variables refer to the characteristics of the situation. Personal bases of power reflect the leader's personality features, which play an important role in how powerful he or she feels (Anderson et al., 2012; Kocur, 2017). With the notion of an existing void in the topic of personal sources of contemporary managers' influence (Judge et al., 2008), this article aims to explore the topic of personal bases (dispositional sources) of power and influence and its exercise and regulation.

\section{Influence Tactics and Influence Regulation}

One of the most critical and challenging tasks for managers is influencing subordinates in a way that effectively motivates them to carry out requests and strengthens their commitment to making decisions (Kipnis et al., 1980; Yukl \& Falbe, 1990). For such purpose, proactive influence tactics are used. The purpose of applying them is to incorporate individuals with useful personal resources or encourage them to accept managerial suggestions. In some cases, they are forms 
of support to aid in completing a task. Hence, proactive influence tactics are different from other tactics, of which the aim is to manage impressions, win affection, or improve the level of one's assessed skills (Doliński, 2011). In this article, a tactic of influence is understood as a method of progressing in a task, used as a particular behavior in a given situation (Kożusznik, 2005).

Yukl et al. (2005) developed a classification of proactive influence tactics, which is widely accepted in modern research. Their classification encompasses 11 tactics ordered in three categories: hard, soft, and rational. Hard tactics, i.e., exchange, pressure, legitimating, and coalition, use strict and decisive ways of doing things such as controlling, threatening, stress, and contesting. They often help the manager block out adversarial behavior or make it stop being attractive. Soft tactics, i.e., inspirational appeals, collaboration, ingratiation, consultation, and personal appeals, are based on expressing understanding for others, supporting them, and fostering their goals. Presenting this kind of attitude towards others leads to obtaining acceptance for submitted requests. Subforms of soft tactics are rational tactics of rational persuasion and apprising, in which the agent of influence explains and convinces others to his or her proposals by providing arguments and presenting evidence.

Among managers, the four most commonly used tactics of influence are cooperation, rational persuasion, consultation, and inspirational appeals (Trinkle \& Lam, 2014). The same influence tactics are considered the most effective. In contrast, the least effective tactics are pressure, coalition, and legitimating (Yukl \& Tracey, 2003). Kennedy et al. (2003) showed results that are partially consistent with these findings. Their cross-cultural research indicates that rational persuasion, consultation, collaboration, and apprising are the most effective. Emans et al. (2003) noted that exerting soft influence is more effective than hard influence. Furthermore, the results of the study conducted by Yukl and Tracey (1995) indicate that consultation is strongly positively linked to rational persuasion, inspirational appeals, and ingratiation. Legitimization tactic strongly correlates with coalition and moderately with pressure and personal appeals. The tactic of personal appeals is in relation to exchange and ingratiation. No significant negative correlations between tactics were observed. Moreover, the research of Case et al. (1988) shows that exerting two influence tactics brings more favorable outcomes than using only a single tactic. However, the effectiveness of a particular combination depends on what types of tactics are combined (Falbe \& Yukl, 1992). Combining two soft tactics is more effective than using a single soft tactic. Applying two hard tactics is not significantly different from using a single 
hard tactic. Exercising a hard tactic with rational persuasion is more effective than using a single hard tactic or rational persuasion alone. Yielding a hard tactic with a soft tactic is more effective than using a single hard tactic, but not significantly different from using a single soft tactic. At last, combining two soft tactics is substantially more effective than combining two hard tactics.

In the discussion on influence tactics, we find it essential to note the phenomenon of influence regulation, namely Deinfluentization (DEI). DEI is a psychological construct describing the ability, willingness, and skill to regulate one's influence. It is based on a conscious detection of influence and its source. It has behavioral consequences, such as reduction or removal of one's influence when the influence of another person or group is adequate to meet the requirements of a situation. DEI encompasses two dimensions: reducing one's meaning and offering space for other organization members. Reducing one's meaning is based on auto-suppressing one's will to dominate as well as the acknowledgment and acceptance of one's vulnerability. It is manifested in behaviors such as stopping, listening, staying silent, and waiting for others' actions. Offering space for others is an act of behavior that allows others to exert their power and influence. The manager's acquiescence for expressing the will of others is followed by other members feeling supported and encouraged to behave more actively, to speak up, and present their points of view or ideas. Therefore, DEI managers play an important role in organizations, as allowing others to use their power and influence helps them to fulfill their needs and achieve their individual, as well as organizational goals (Kożusznik, 2005).

\section{Personal Determinants of Power (Big Five, Directiveness)}

Since personal power can stem from an individual's characteristics, personality is of particular interest in our study. Personality traits are determinants of the tendency to display specific behaviors (Mischel, 2004, as cited in Cieciuch \& Łaguna, 2014). As a constellation, they regulate an individual's functioning, supporting, or changing presented actions, which is reflected in the manager's activities undertaken to achieve organizational goals (Cable \& Judge, 2003). A model that merges the knowledge gathered under different theoretical approaches (Saucier \& Srivastava, 2015) and that is marked as the one which provides an integrative descriptive model for research (John \& Srivastava, 1999; de Raad, 1998) is the Big Five. Hence, it is often used to measure personality traits (Gorbaniuk et al., 2019), and is considered to describe the most salient 
aspects of personality among leaders (Judge et al., 2002). Managerial effectiveness is ensured by Conscientiousness, as it determines individual's goal orientation (Bono \& Judge, 2004; Barrick \& Mount, 1991), Openness to Experience, which is the tendency to seek for new opportunities and solutions, and Extraversion, as it is reflected in building and maintaining one's social network (Brandstätter, 2011). Achieving effectiveness is not, however, supported by Neuroticism, which leads to suspicion in social relations (Brown \& Trevino, 2006). Similarly, Agreeableness is not seen as auspicious for managerial success due to the need for affiliation experienced by the manager (McClelland \& Boyatzis, 1982). Nevertheless, researchers agree that Agreeableness entails cooperative attitude, contrariwise to competitive attitude, characteristic of low agreeable people (Zawadzki et al., 1998).

In the organizational context, there is little research examining personality in relation to power and influence (Judge et al., 2008). In the studies on the use of influence tactics, it was found that people with higher needs for power and achievement were more likely to employ them (Mowday, 1978). Theoretical considerations suggest that Extraversion and Conscientiousness may be predictors of more frequent use of influence tactics (Ferris et al., 2005; Caldwell \& Burger, 1997). However, only one such research was undertaken, and it was assumed that different personality traits might play a role in choosing specific influence tactics (Cable \& Judge, 2003). One of them, of particular relation with exerting influence over others, is directiveness.

Ray $(1971,1976)$ developed the idea of directiveness as a result of his critique of Adorno et al.'s (1950) authoritarian personality syndrome. He argued that attitudes and behavior do not always complement each other, and there is little to no relationship between them. On such a notion, Ray (1976) suggested that what should be studied is the authoritarianism of personality rather than the authoritarian attitude, as only the former is strongly related to behavior. The authoritarian personality trait was termed directiveness, and Ray (1976) subsequently claimed that an authoritarian person (high in directiveness) is someone who has the desire or tendency to impose their will on others and behaves in a domineering and destructive way towards them. Directiveness is an indispensable feature of effective leadership (Jasiński \& Wilczyńska, 2015). However, because directiveness is associated with achievement motivation (Czerniawska, 2018), aggression, assertiveness, and power (Jasiński \& Wilczyńska, 2015; Turska-Kawa \& Wojtasik, 2017), highly directive managers have the tendency to make decisions without considering other people's opinions or abuse power 
by excessively punishing subordinates. Nonetheless, there are some instances in which they obtain good results. When fast or tough decisions are of great need, individuals who want to take control of the crisis (and others) bring valuable resources to the equation.

\section{The Personal Sense of Power}

Personal bases of power play an important role in one's power and influence related behavior. However, they are not substantial enough to explain the full scope of individuals' functioning in organizations. Maslow (1937, as cited in Bennett, 1988, p. 365) made a distinction between "craving for dominance" and "dominance-feeling." The former refers to the motivation to have an advantage over others and the desire to impose one's will on others, while the latter applies to a feeling of pride or sense of superiority. To be the most effective, an individual must not only possess particular personal characteristics but also feel that he or she is respected in relationships with others.

As noted by Anderson et al. (2012), power neither does only relate to having control over resources, nor does it solely stem from social position. As a perception of one's capacity to influence others, the sense of power is different from socio-structural sources of power and entails a more effective way of behaving (Anderson et al., 2012; Bandura, 1999; Bugental \& Lewis, 1999). Analyses conducted by Anderson et al. (2012) indicate that one's perception of having the ability to exert power over others is relationship-specific. Furthermore, the personal sense of power correlates with socio-structural sources of power, such as sociometric status and ability to control resources, albeit moderately. Personality variables are of equal importance in shaping one's feeling of being powerful. As observed, the personal sense of power is positively related to Extraversion, Conscientiousness, and Openness to Experience, but negatively to Neuroticism. No significant correlation was found between the personal sense of power and Agreeableness (Anderson et al., 2012). Also, Yang et al. (2018) proved that the sense of power was positively related to cooperation, and research done by Cislak et al. (2018) showed that, although power over others correlates with antisocial tendencies, personal control was negatively associated with them. 


\section{RESEARCH PART}

\section{Study 1: The Frequency of Use of Influence Tactics}

The impetus for the study was little existing information about the tactics of influence used by Polish managers. Isolated examples include reports of a tendency to express authoritarian leadership style (Mączyński et al., 1993), existing manorial-serf culture in which superiors abuse their total power and behave in an oppressive manner unlimited by any permissions (Hryniewicz, 2007; Santorski $\&$ Michalik, 2016), or the analysis of preferences of using tactics depending on the age or presented forms of leadership (Paliga \& Pollak, 2016). Hence, study 1 was designed to gather more data about influence tactics and better describe the frequency of their use among Polish managers. Since the aim was exploratory, no particular hypothesis was formed.

\section{METHOD}

\section{Participants and procedure}

The authors recruited the participants from their contact network. The respondents were given a paper questionnaire with the assurance that all results would be computed with anonymity and confidentiality. Participation in the research was voluntary.

The sample in the study comprised 250 managers (139 men and 107 women; 4 did not provide information about their gender). The majority of participants $(61 \%)$ graduated with the title of MSc, $10 \%$ of them had a bachelor's degree, $26 \%$ had secondary education, and $4 \%$ had Polish National Vocational Qualification. Respondents from companies of assorted size were included in the sample almost equally. Managers' seniority ranged from 4 months year to 45 years $(M=15.25, S D=10.68)$, with years of experience in current position from 4 months year to 30 years $(M=7.24, S D=6.67)$.

\section{Measure}

All participants were asked to fill out the Influence Behavior Questionnaire (IBQ; Yukl \& Seifert, 2002), a self-report measure for assessing 11 proactive hard, soft, and rational influence tactics, including pressure, legitimating, coali- 
tion, exchange, ingratiation, consultation, inspirational appeals, personal appeals, collaboration, rational persuasion, and apprising. The questionnaire consists of 33 items (3 items for each tactic) with the response scale from $1=I$ can't remember I ever used this tactic to $5=I$ use this tactic very often. In the original measure the obtained reliability score exceeded .70 for all tactics. In the study, Cronbach's $\alpha$ ranged from .61 (pressure) to .80 (inspirational appeals).

\section{Results}

To verify the hypotheses, we analyzed the gathered data using SPSS 25 and Statistica 25. To compare the frequency of influence tactics, the non-parametric Friedman rank test was performed. The results were statistically significant: $\chi^{2}(N=250, d f=10)=1075.86 ; p<.001$. Their graphical representation is presented in Figure 1.

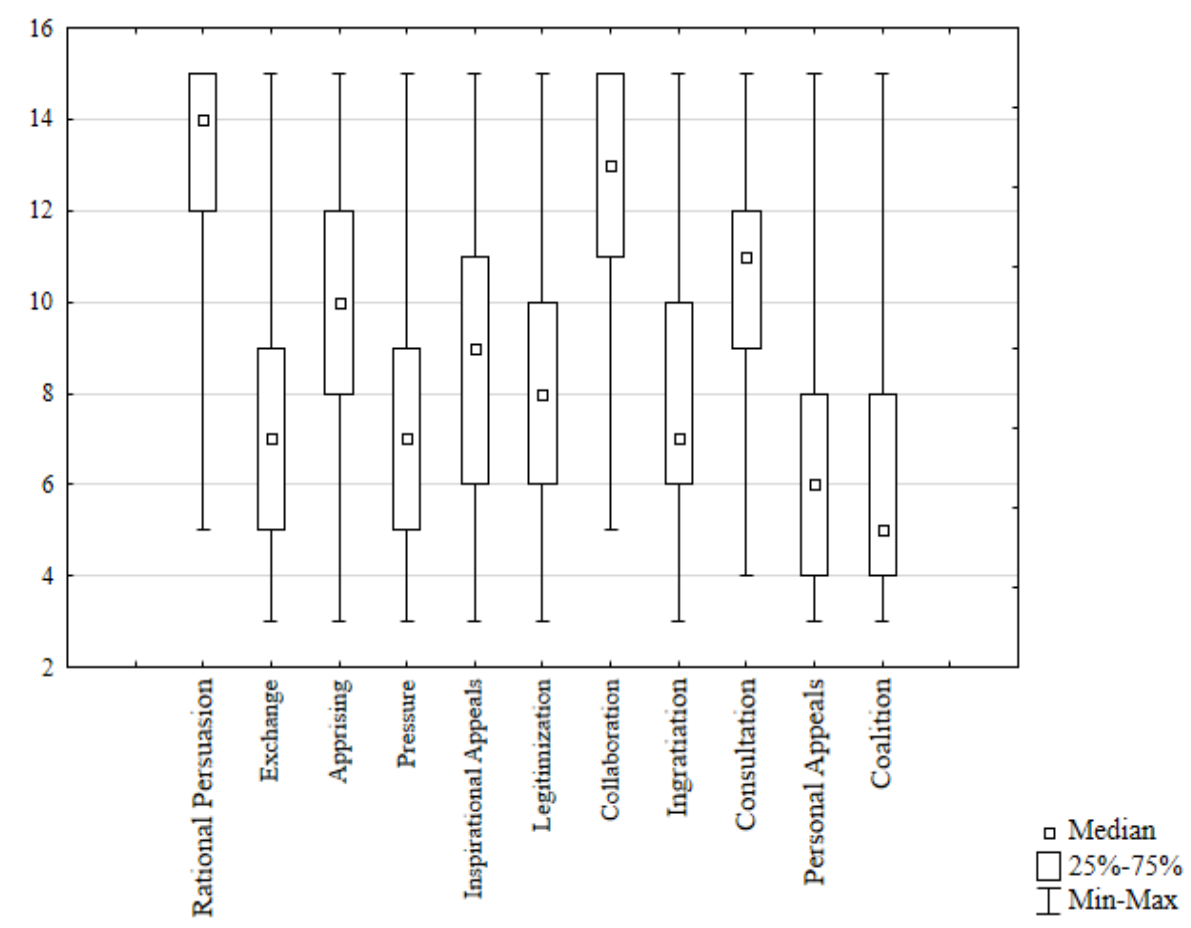

Note. $n=250$.

Figure 1. Frequency of Influence Tactics Use 
The results suggest that there is no statistically significant difference between rational persuasion and collaboration $(z=.61 ; p=.04)$, two tactics that are used with the highest frequency. However, both rational persuasion and collaboration are used more often than apprising $(z=2.49 ; p<.001 ; z=-1.88, p<.001$, respectively) and consultation ( $z=2.41 ; p<.001 ; z=1.8 ; p<.001$, respectively), which in turn are exercised more often than inspirational appeals $(z=1.40$; $p<.001$ for apprising and $z=-1.48 ; p<.001$ for consultation). Moreover, managers use inspirational appeals as frequently as legitimizing $(z=.37 ; p>.05)$ and ingratiation $(z=.81 ; p>.05)$. All these three tactics are used more often than exchange $(z=-1.23 ; p<.001$ for inspirational appeals, $z=-.86 ; p<.001$ for legitimizing, and $z=-.42 ; p<.001$ for ingratiation) and pressure $(z=-1.67$; $p<.001$ for inspirational appeals, $z=-1.30 ; p<.001$ for legitimizing, and $z=-.86 ; p<.001$ for ingratiation). Furthermore, exchange is more frequent than personal appeals $(z=1.02 ; p<.001)$ and coalition $(z=1.10 ; p<.001)$. Finally, no statistical differences are found between the frequency of using pressure, personal appeals, and coalition.

Concerning the theoretical coexistence of various tactics of influence in managerial actions and the observed benefits combining different tactics in the same influence attempt (Falbe \& Yukl, 1992), an aim was made to determine the degree and direction of the existing covariance between specific tactics in the study sample. Correlations among influence tactics were measured with the use of Spearman's rho coefficient because of the non-parametric distributions of the variables. The results of the Kolmogorov-Smirnov normality test and correlations are shown in Table 1.

The results show that there are several positive and moderate or weak correlations among influence tactics. Rational persuasion correlates positively with collaboration (rho $=.32 ; p<.01$ ). Exchange correlates positively with ingratiation (rho $=.38 ; p<.01$ ), personal appeals (rho $=.36 ; p<.01$ ), and coalition (rho $=.32 ; p<.01)$. Apprising correlates positively with inspirational appeals $(\mathrm{rho}=.37 ; p<.01)$ and ingratiation $(\mathrm{rho}=.33 ; p<.01)$. Pressure correlates positively with legitimating (rho $=.31 ; p<.01)$. Inspirational appeals correlates positively with ingratiation ( $\mathrm{rho}=.38 ; p<.01)$, consultation ( $\mathrm{rho}=.32 ; p<.01)$, and collaboration (rho $=.30 ; p<.01$ ). Collaboration correlates positively with consultation (rho $=.35 ; p<.01$ ). Ingratiation correlates positively with personal appeals (rho $=.31 ; p<.01)$. Personal appeals correlates positively with coalition $($ rho $=.36 ; p<.01)$. 
Table 1. Intercorrelations Between Influence Tactics

\begin{tabular}{|c|c|c|c|c|c|c|c|c|c|c|c|c|c|}
\hline & $\begin{array}{r}\mathrm{K}- \\
(d f=\end{array}$ & $\begin{array}{l}\mathrm{S} \\
250)\end{array}$ & 1 & 2 & 3 & 4 & 5 & 6 & 7 & 8 & 9 & 10 & 11 \\
\hline & Stat. & Sig. & & & & & & & & & & & \\
\hline $\begin{array}{l}\text { Rational } \\
\text { persuasion }\end{array}$ & .20 & .01 & $(.70)$ & -.01 & $.28^{* *}$ & -.10 & $.25^{* *}$ & .10 & $.32^{* *}$ & .11 & $.15^{*}$ & $-.15^{*}$ & .07 \\
\hline Exchange & .10 & .01 & & $(.71)$ & $.25^{* *}$ & $.19^{* *}$ & $.21^{* *}$ & .09 & -.03 & $.38^{* *}$ & -.04 & $.36^{* *}$ & $.32^{* *}$ \\
\hline Apprising & .10 & .01 & & & $(.79)$ & .02 & $.37^{* *}$ & $.15^{*}$ & $.25^{* *}$ & $.33^{* *}$ & $.25^{* *}$ & .03 & .06 \\
\hline Pressure & .11 & .01 & & & & $(.61)$ & $-.18^{* *}$ & $.31^{* *}$ & -.10 & $.18^{* *}$ & $-.24^{* *}$ & .03 & $.20^{* *}$ \\
\hline $\begin{array}{l}\text { Inspirational } \\
\text { appeals }\end{array}$ & .09 & .01 & & & & & $(.80)$ & $.13^{*}$ & $.30^{* *}$ & $.38^{* *}$ & $.32^{* *}$ & .08 & .02 \\
\hline Legitimating & .09 & .01 & & & & & & $(.70)$ & .03 & .11 & -.01 & .07 & .10 \\
\hline Collaboration & .15 & .01 & & & & & & & $(.76)$ & $.20^{* *}$ & $.35^{* *}$ & -.02 & $-.16^{*}$ \\
\hline Ingratiation & .11 & .01 & & & & & & & & $(.69)$ & $.13^{*}$ & $.31^{* *}$ & $.23^{* *}$ \\
\hline Consultation & .11 & .01 & & & & & & & & & (.78) & .01 & -.07 \\
\hline $\begin{array}{l}\text { Personal } \\
\text { appeals }\end{array}$ & .14 & .01 & & & & & & & & & & $(.76)$ & $.36^{* *}$ \\
\hline Coalition & .16 & .01 & & & & & & & & & & & $(.72)$ \\
\hline
\end{tabular}

Note. $\mathrm{K}-\mathrm{S}=$ Kolmogorov-Smirnov; alpha coefficients are in parentheses; $n=250$.

${ }^{*} p<.05 .{ }^{* *} p<.01$.

\section{Study 2: Personal Sense of Power and Influence Tactics}

The aim of Study 2 was to investigate the relationship between the personal sense of power and influence tactics. Anderson et al. (2012) noted how an individual's perception of his or her capacity to influence others is related to the ability to control their actions. The authors assume that individuals with a high personal sense of power attribute others' behavior to the control that they exert. Such a phenomenon would have specific consequences for managers' functioning in organizations. It entails that supervisors who perceive their ability to control subordinates as high, to change their behaviors and fulfill the goals, would turn to use hard and rational influence tactics. However, it does not mean that individuals with a high sense of power will not use soft influence tactics. After 
all, the aim of using influence tactics is to behave effectively, and people perceiving their power as high can do that (Bandura, 1999; Bugental \& Lewis, 1999), no matter the strength of influence. Indeed, some research suggests that low confidence tends to be related to coercive influence tactics (Goodstadt \& Hjelle, 1973; Raven \& Kruglanski, 1970). Nevertheless, it would be parsimonious to think that formal superiors' low sense of personal power equals the use of only soft influence tactics. Based on existing theoretical and practical premise, the following hypothesis was formulated:

$\mathrm{H}$ 1: There is a positive correlation between the personal sense of power and hard, rational, and soft influence tactics.

\section{METHOD}

\section{Participants and procedure}

The questionnaires were distributed by the authors and students within their contact network. The managers were provided with a set of paper questionnaires, then assured of the anonymity and confidentiality of the research. Participation in the study was voluntary.

A sample of 104 Polish managers completed the questionnaires (53 men and 49 women; 2 did not specify their gender). The participants ranged in age from 21 to 68 years $(M=38.52, S D=10.38)$. The majority of participants $(63 \%)$ had a master's degree, $12.5 \%$ graduated with a bachelor's degree, $21 \%$ had secondary education, and $4 \%$ had Polish National Vocational Qualification. Out of all participants, $19 \%$ of them were employed in micro-companies, $30 \%$ in small organizations, $20 \%$ worked for medium-sized companies, and 33\% for big companies. The seniority of the participants ranged from 1 year to 45 years $(M=14.54$, $S D=10.53)$, with years of experience in the current position from 1 year to 27 years $(M=6.34, S D=5.96)$.

The participants answered the Influence Behavior Questionnaire (IBQ) and the Sense of Power Scale. As regards IBQ (Yuk1 \& Seifert, 2002), they filled out the same questionnaire as in Study 1. In Study 2 Cronbach's $\alpha$ ranged from .64 (pressure) to .83 (collaboration and coalition). The Sense of Power Scale (Anderson et al., 2012) was used to measure the perception of one's capacity to influence others. The participants were asked to answer 8 questions concerning their 
perception of power in their relationships with subordinates (a sample item: "I can get my subordinates to listen to what I say"). The response scale ranges from $1=$ strongly disagree to $7=$ strongly agree. The reliability of the original scale was from .82 to .85 , whereas in the present study, Cronbach's $\alpha$ was .88 .

\section{Results}

To verify the hypothesis, we analyzed the collected data using SPSS 25. Due to the non-normal distribution of the variables, correlations were computed using Spearman's rho coefficient. Descriptive statistics with Kolmogorov-Smirnov normality test results for influence tactics and personal sense of power and correlations among them are shown in Table 2.

Table 2. Descriptive Statistics for Influence Tactics and Personal Sense of Power in Study 2 and Spearman's Rank Correlations Between Variables

\begin{tabular}{|c|c|c|c|c|c|c|}
\hline & \multirow[t]{2}{*}{$M e$} & \multirow[t]{2}{*}{$M$} & \multirow[t]{2}{*}{$S D$} & \multicolumn{2}{|c|}{$\begin{array}{c}\text { Kolmogorov-Smirnov } \\
(d f=104)\end{array}$} & \multirow{2}{*}{$\begin{array}{c}\text { Personal } \\
\text { Sense } \\
\text { of Power }\end{array}$} \\
\hline & & & & Statistic & Sig. & \\
\hline Rational persuasion & 14 & 13.45 & 1.78 & .21 & .01 & $.25^{*}$ \\
\hline Exchange & 8 & 7.66 & 3.03 & .10 & .01 & -.19 \\
\hline Apprising & 11 & 10.48 & 2.96 & .10 & .01 & $.20^{*}$ \\
\hline Pressure & 7 & 6.99 & 2.56 & .12 & .01 & $.20^{*}$ \\
\hline Inspirational appeals & 10 & 9.21 & 3.35 & .12 & .01 & .06 \\
\hline Legitimating & 8 & 8.03 & 3.04 & .10 & .02 & -.18 \\
\hline Collaboration & 13 & 12.54 & 2.44 & .16 & .01 & .03 \\
\hline Ingratiation & 8 & 7.99 & 3.03 & .11 & .01 & -.02 \\
\hline Consultation & 11 & 10.42 & 2.69 & .12 & .01 & -.10 \\
\hline Personal appeals & 6 & 6.59 & 3.19 & .15 & .01 & -.13 \\
\hline Coalition & 6 & 6.58 & 2.80 & .16 & .01 & -.03 \\
\hline Personal Sense of Power & 45 & 44.90 & 5.86 & .10 & .02 & - \\
\hline
\end{tabular}

Note. $n=104 .{ }^{*} p<.05$.

The results show that among all influence tactics, personal sense of power correlates positively with rational tactics of rational persuasion (rho $=.25$; $p<.05)$ and apprising (rho $=.20 ; p<.05)$. It also correlates with the hard tactic of pressure $(\mathrm{rho}=.20 ; p<.05)$. All correlations are weak but significant. 


\section{Study 3: Personality and Influence}

In Study 3, we investigated the relationships of personal determinants of power (Big Five, directiveness) with influence tactics and influence regulation (DEI).

To the authors' knowledge, there is only one study examining the relationship between the Big Five and influence tactics. Results of Cable and Judge (2003) revealed that managers who scored high on Extraversion were more likely to employ inspirational appeals and ingratiation. Those who had high scores on the Neuroticism scale were less likely to engage in rational persuasion and more likely to apply inspirational appeals. The managers with higher Agreeableness were less likely to engage in legitimizing and pressure. The respondents who scored higher in Conscientiousness often showed greater use of rational persuasion but did not employ personal appeals. Finally, a negative correlation between Openness to Experience and coalition tactic was found. No research has ever been conducted to investigate the relationship between personality traits and influence tactics of Polish managers. Thus, Hypotheses $\mathrm{H} 1$ to $\mathrm{H} 5$ were adopted from Cable and Judge's study (2003):

- H 1: There is a positive correlation between Extraversion and inspirational appeals and ingratiation

- H2: There is a positive correlation between Conscientiousness and rational persuasion and a negative correlation between Conscientiousness and personal appeals

- H3: There is a negative correlation between Agreeableness and legitimizing and pressure

- H4: There is a negative correlation between Openness to Experience and coalition

- H 5: There is a negative correlation between Neuroticism and rational persuasion and inspirational appeals.

There is a well-grounded approach that directiveness bears a positive correlation with aggression and dominance but a negative correlation with submissiveness (Ray, 1981). Also, the basis of directiveness is the belief in the correctness of one's behavior (Ray, 1978, as cited in Brzozowski, 1997). Because only hard tactics are based on a strict and decisive influence, we expect all correlations between directiveness and hard tactics to be positive (H6). Contrariwise, in the case of the correlations of directiveness with soft tactics, we expect them to be negative (H7). Therefore, the following hypotheses were formulated: 
- H6: There is a positive correlation between directiveness and hard tactics

- H7: There is a negative correlation between directiveness and soft tactics.

The assumption of DEI is that a manager decides to reduce his or her influence when they see their influence as ineffective or the influence of others is viewed as better in goal attainment (Kożusznik, 2005). The essence of DEI is that one's influence is an instrument for achieving effectiveness and not an attribute of meaning and power. In a similar vein, it has been proved that personality traits are related to effectiveness, as they predict school performance and are relevant for future work success (Judge et al., 1999; Spengler et al., 2018). Neuroticism, however, concerns feeling negative emotions in relationships with others, especially tension and anxiety. It can subsequently disrupt adaptive coping with stress and stop a neurotic individual from resigning from his or her position and sharing influence with others. Hence, we assume that all of the Big Five traits will be related to DEI, and the only negative correlation will be between DEI and Neuroticism (H 8).

Furthermore, Celińska-Nieckarz et al. (2012) noted that authoritarians could be more condescending and show greater hostility to people of lower status. The authors proved that a higher perceived level of directiveness is associated with a higher perceived task performance. Also, a lower perceived level of directiveness goes with a higher perception of effectiveness in building relationships. Contrariwise, DEI stems from cooperative orientation and entails goal attainment at a group level (Kożusznik et al., 2018). Because the execution of a managerial role requires choosing organizational goals over personal ones, and cooperation requires positive relationships, we expect a negative correlation between directiveness and DEI (H9).

Upon existing theoretical premise, the following hypotheses were formulated:

- H 8: There is a positive correlation between Extraversion, Agreeableness, Conscientiousness, Openness to Experience and DEI, and a negative correlation between Neuroticism and DEI

- H9: There is a negative correlation between directiveness and DEI.

\section{METHOD}

\section{Participants and procedure}

The questionnaires were distributed by the authors and students within their contact network. The respondents were provided with a set of paper question- 
naires and assured of the anonymity and confidentiality of the research. Participation in the research was voluntary. 69 managers ( 36 men and 29 women; 4 did not provide information about their gender) took part in the study. The age of participants ranged from 20 to 64 years $(M=40.22, S D=11.01)$. Most of the respondents had a degree in higher education, either master $(56.4 \%)$ or bachelor (7.2\%). The rest of the members (36.2\%) had secondary education. 36\% participants worked for big enterprises ( 250 employees or more), $27.5 \%$ in mediumsized organizations (50-249), 24.7\% in small businesses (10-49 employees), and $17.4 \%$ came from micro-companies (fewer than 9 employees). The average seniority of managers was 18.27 years $(S D=10.98)$, with the average number of years of experience in the current position at 8.17 years $(S D=6.88)$. In most cases $(68.1 \%)$, the participants were promoted within one company, $18.8 \%$ changed their jobs to be promoted in a different company, the rest $(7.2 \%)$ had been promoted in one company and then moved to another.

\section{Measures}

NEO Five-Factor Inventory (Costa \& McCrae, 1992; Polish adaptation: Zawadzki et al., 1998) to assess Neuroticism, Extraversion, Openness to Experience, Agreeableness, and Conscientiousness. The scale comprises 60 items. The answer format is a 5-point Likert scale: from $1=$ strongly disagree to $5=$ strongly agree. Cronbach's $\alpha$ ranged from .76 for Agreeableness to .85 from Neuroticism.

D Scale (Ray, 1976; Polish adaptation: Brzozowski, 1997) to assess the personality trait of directiveness, manifested by the desire or tendency to impose one's will on others. The scale consists of 26 items with the response scale from $1=$ yes to $3=$ no. Cronbach's $\alpha$ was .76 .

DEI-beh Scale (Kożusznik et al., 2015) to measure Deinfluentization and reduction of one's influence. The scale comprises 24 items with a response scale from 1 = never to $5=$ always. Cronbach's $\alpha$ ranged from .82 (Deinfluentization) to .73 (Meaning Reduction), and to .53 (Space Offering).

Influence Behavior Questionnaire (Yukl \& Seifert, 2002). In Study 3 Cronbach's $\alpha$ ranged from .52 (exchange) to .78 (apprising). 


\section{Results}

The following analyses were conducted in SPSS 25. To test the hypotheses, we employed the non-parametric tests and the Spearman's rho correlation coefficient due to the non-normal distribution of variables (Table 3).

Table 3. Descriptive Statistics for the Big Five, Directiveness, and Deinfluentization

\begin{tabular}{lrrrrrrr} 
& Min & Max & Me & $M$ & \multirow{2}{*}{ SD } & \multicolumn{2}{c}{ Shapiro-Wilk $(d f=69)$} \\
& & & & & & Statistic & Sig. \\
\hline Neuroticism & 4 & 40 & 16 & 16.72 & 7.74 & .96 & .02 \\
Extraversion & 15 & 42 & 31 & 30.30 & 6.60 & .96 & .02 \\
Openness to Experience & 8 & 41 & 26 & 26.33 & 7.11 & .99 & .88 \\
Agreeableness & 11 & 42 & 31 & 30.12 & 6.50 & .96 & .04 \\
Conscientiousness & 18 & 46 & 37 & 35.58 & 6.16 & .95 & .01 \\
Deinfluentization & 41 & 87 & 70 & 70.26 & 8.42 & .77 & .01 \\
Meaning Reduction & 18 & 45 & 34 & 34.30 & 5.31 & .86 & .01 \\
Space Offering & 23 & 44 & 36 & 35.94 & 4.15 & .76 & .01 \\
Lie scale & 10 & 24 & 16 & 16.43 & 2.63 & .77 & .01 \\
Directiveness & 38 & 78 & 60 & 60.68 & 8.33 & .99 & .83 \\
\hline
\end{tabular}

Note. $n=69$. The Lie scale is included in the DEI-beh questionnaire.

The participants' scores in NEO-FFI and D Scale (Table 3) indicate that they can be characterized as moderate in assessed traits. In the case of Neuroticism, $79 \%$ of the results are in the moderate and low scores interval. It shows that the subjects do not tend to frequently and intensively feel negative emotions, uncertainty, anger, irritation, and they handle social situations well.

Table 4. Pearson's Correlations and Spearman's Rank Correlations Between the Big Five and Influence Tactics

\begin{tabular}{|c|c|c|c|c|c|c|c|c|c|c|c|}
\hline & 1 & 2 & 3 & 4 & 5 & 6 & 7 & 8 & 9 & 10 & 11 \\
\hline Neuroticism & $-.30^{*}$ & .09 & & $.24^{*}$ & -.02 & $.27^{*}$ & -.13 & -.05 & $-.25^{*}$ & .08 & $.37^{* *}$ \\
\hline Extraversion & $.27^{*}$ & .04 & & -.09 & .20 & -.13 & .02 & .05 & .10 & .13 & -.16 \\
\hline $\begin{array}{l}\text { Openness to } \\
\text { Experience }\end{array}$ & .19 & .04 & & -.11 & $.27^{*}$ & $-.27^{*}$ & .10 & .15 & .16 & .02 & -.21 \\
\hline Agreeableness & .12 & -.12 & & $-.44^{* *}$ & .16 & -.19 & .13 & -.04 & .19 & -.01 & $-.29^{*}$ \\
\hline Conscientiousness & $.24^{*}$ & -.02 & & -.03 & .08 & .15 & .11 & .04 & .20 & -.04 & -.06 \\
\hline
\end{tabular}

Note. $n=69.1$ = Rational persuasion, $2=$ Exchange, $3=$ Apprising, $4=$ Pressure, $5=$ Inspirational appeals, $6=$ Legitimating, $7=$ Collaboration, $8=$ Ingratiation, $9=$ Consultation, $10=$ Personal appeals, $11=$ Coalition. ${ }^{*} p<.05 .{ }^{* *} p<.01$.

Table 4 shows that Neuroticism correlates negatively with rational persuasion $($ rho $=-.30 ; p<.05)$ and consultation (rho $=-.25 ; p<.05)$ and positively 
with coalition (rho $=.37 ; p<.01)$ and legitimating (rho $=.27 ; p<.05)$. Extraversion correlates positively with rational persuasion ( $\mathrm{rho}=.27 ; p<.05$ ). Openness to Experience correlates negatively with legitimating (rho $=-.27 ; p<.05)$ and positively with inspirational appeals (rho $=.27 ; p<.05$ ). Agreeableness correlates negatively with pressure $($ rho $=-.44 ; p<.01)$ and coalition $($ rho $=-.29$; $p<.05)$. Conscientiousness correlates positively with rational persuasion $($ rho $=.24 ; p<.05)$.

Table 5. Spearman's Rank Correlations Between Directiveness and Influence Tactics

\begin{tabular}{lccccccccccc}
\hline & 1 & 2 & 3 & 4 & 5 & 6 & 7 & 8 & 9 & 10 & 11 \\
\hline Directiveness & 0 & .15 & .21 & $.24^{*}$ & .06 & .09 & .05 & $.33^{* *}$ & -.02 & $-.27^{*}$ & .08 \\
\hline
\end{tabular}

Note. $n=69.1$ = Rational persuasion, $2=$ Exchange, $3=$ Apprising, $4=$ Pressure, $5=$ Inspirational appeals, $6=$ Legitimating, $7=$ Collaboration, $8=$ Ingratiation, $9=$ Consultation, $10=$ Personal appeals, $11=$ Coalition. ${ }^{*} p<.05 .{ }^{* *} p<.01$.

Table 5 shows that Directiveness correlates positively and weakly with pressure $($ rho $=.24 ; p<.05)$ and ingratiation $($ rho $=.33, p<.01)$, and negatively and weakly with personal appeals (rho $=-.27 ; p<.05)$.

Table 6. Spearman's Rank Correlations Between the Big Five and Deinfluentization and Its Dimensions

\begin{tabular}{lccccc}
\hline & Neuroticism & Extraversion & $\begin{array}{c}\text { Openness } \\
\text { to Experience }\end{array}$ & Agreeableness & Conscientiousness \\
\hline Deinfluentization & -.17 & .16 & .14 & $.37^{* *}$ & .21 \\
Meaning Reduction & -.03 & .01 & -.05 & $.25^{*}$ & .04 \\
Space Offering & $-.29^{*}$ & .23 & $.27^{*}$ & $.44^{* *}$ & $.27^{*}$ \\
\hline
\end{tabular}

Note. $n=69 .{ }^{*} p<.05 .{ }^{* *} p<.01$.

As presented in Table 6, Deinfluentization and its dimension of Meaning Reduction correlate positively and weakly with Agreeableness ( rho $=.37 ; p<.01$; and rho $=.25 ; p<.05$, respectively), while Space Offering correlates with it at a moderate level (rho $=.44 ; p<.01)$. There is also a significant positive correlation between Space Offering and Conscientiousness (rho $=.27 ; p<.01)$ and Openness to Experience (rho $=.27 ; p<.05$ ), and a negative correlation with Neuroticism $($ rho $=-.29 ; p<.05)$. 
Table 7. Spearman's Rank Correlations Between Directiveness and Deinfluentization

\begin{tabular}{lccc} 
& Deinfluentization & Meaning Reduction & Space Offering \\
\hline Directiveness & $-.31^{*}$ & $-.41^{* *}$ & -.11 \\
\hline Note $n=69^{*} p<.05^{* *} p<01$ & &
\end{tabular}

Note. $n=69 .{ }^{*} p<.05 .{ }^{* *} p<.01$.

Table 7 shows that there is a weak negative relationship between directiveness and Deinfluentization and Meaning Reduction (rho $=-.31 ; p<.05$; rho $=-.41 ; p<.01$, respectively).

\section{GENERAL DISCUSSION}

All three studies were conducted on a pool of formal managers, whose role is to exert social influence to execute plans and accomplish organizational goals.

The results of the first study show that Polish managers most frequently employ influence tactics such as rational persuasion, collaboration, apprising, consultation, and inspirational appeals. The least exercised influence tactics are pressure, personal appeals, and coalition. The obtained results suggest that Polish managers prefer to apply soft and rational tactics of influence rather than hard ones. It indicates how Polish managers care about psychological work atmosphere, as the tactics just mentioned create understanding, engagement, and evoke positive emotions.

Regarding relationships among influence tactics, results from Study 1 only partially mirror the results obtained by Yukl and Tracey (1995). One vivid similarity is that among all tactics, no negative correlations were observed. In our study, we saw different combinations of hard, soft, and rational influence tactics. The only relationship that was not observed was between rational and hard tactics.

Polish managers present a moderate level of the personal sense of power. The proven positive relationships between the personal sense of power and rational influence tactics may stand as a confirmation for the key role of information in managing subordinates. A manager aware of the importance of information that he or she possesses is also the one who provides logical arguments, evidence supporting their ideas, and explanations to elicit desired behaviors among their subordinates.

As for the relations between influence tactics and personality traits among Polish managers, Extraversion and Conscientiousness are in a positive relation- 
ship with a rational tactic of influence. Agreeableness is negatively related to hard influence tactics. Openness to Experience is negatively associated with a hard influence tactic, but positively to a soft one. Finally, Neuroticism is in a relationship with all kinds of tactics; however, the directions are different: it is positively correlated with hard tactics and negatively with both rational and soft influence tactics. Such findings suggest that managers who enjoy interacting with others and are open to new opportunities and solutions, empathetic and cooperation-driven, as well as conscientious, have the behavioral tendency to employ soft and rational influence tactics while avoiding hard ones. Conversely, neurotic managers, who are suspicious in social relations and frequently feeling negative emotions, tend to use hard tactics of exert influence. Concerning directiveness, it is in a positive relationship with a hard tactic of influence and both positive and negative relationships with soft tactics. It suggests that managers who desire to force their will on others tend to exert different kinds of influence to fulfill their needs.

Regarding influence regulation and personality traits, DEI correlates positively with Agreeableness and negatively with directiveness. Moreover, its dimension of Space Offering is in a positive relationship with Conscientiousness and Openness to Experience. In other words, managers who are altruistic and cooperative, diligent, and task-oriented, as well as curious regulate their influence by reducing their meaning and offering the space that others need to show their influence. Accordingly, they are not prone to imposing their will on others.

Altogether, we conclude that Polish managers present a tendency to soften their power-orientation and decrease aggressive behavior as well as supplementing them with more cooperative attitudes and a behavioral repertoire. Such a picture of the modern-day Polish manager is different from Mączynski et al.'s (1993) description. It shows a shift from power-abusing authoritarians to more rational and cooperation-oriented superiors who are aware of their power and influence.

\section{LIMITATIONS AND FUTURE RESEARCH}

The presented findings are subject to a few limitations. First, the measures that we used in the studies were self-report questionnaires. As a result, the obtained responses may be distorted due to the participants' social desirability bias an or incorrect subjective assessment. Second, with the use of a set of multiple 
questionnaires, the risk of a common method bias has to be considered. Third, the correlational nature of the studies does not allow indicating any causal effects, valuable in personality-behavior research.

To overcome the limitations, researchers should employ multiple-source and multiple-waves data collection. Furthermore, because the presented studies are correlational, future research should be based on methods that allow discovering dispositional and situational determinants and consequences of influence tactics.

\section{REFERENCES}

Adorno, T. W., Frenkel-Brunswick, E., Levinson, D. J., \& Sanford, R. N. (1950). The authoritarian personality. Harper.

Anderson, C., John, O. P., \& Keltner, D. (2012). The personal sense of power. Journal of personality, 80(2), 313-344.

Anderson, C., Spataro, S. E., \& Flynn, F. J. (2008). Personality and organizational culture as determinants of influence. Journal of Applied Psychology, 93(3), 702-710.

Bandura, A. (1999). Social cognitive theory: An agentic perspective. Asian Journal of Social Psychology, 2(1), 21-41.

Barrick, M. R., \& Mount, M. K. (1991). The big five personality dimensions and job performance: A meta-analysis. Personnel Psychology, 44(1), 1-26. https://doi.org/10.1111/j.1744-6570. 1991.tb00688.x

Bennett, J. B. (1988). Power and influence as distinct personality traits: Development and validation of a psychometric measure. Journal of Research in Personality, 22(3), 361-394. https://doi.org/10.1016/0092-6566(88)90036-0

Bono, J. E., \& Judge, T. A. (2004). Personality and transformational and transactional leadership: A meta-analysis. Journal of Applied Psychology, 89(5), 901-910. https://doi.org/10.1037/ 0021-9010.89.5.901

Boughton, M. (2011). Power, influence tactics, and influence processes in virtual teams (Doctoral dissertation, University of North Carolina, Charlotte, NC). Retrieved March 13, 2020 from https://pdfs.semanticscholar.org/79c7/a68d2f56426f8071d3046e16c0108e6cad7e.pdf

Brandstätter, H. (2011). Personality aspects of entrepreneurship: A look at five meta-analyses. Personality and Individual Differences, 51(3), 222-230. https://doi.org/10.1016/j.paid. 2010.07.007

Brown, M. E., \& Treviño, L. K. (2006). Ethical leadership: A review and future directions. The Leadership Quarterly, 17(6), 595-616. https://doi.org/10.1016/j.leaqua.2006.10.004

Brzozowski, P. (1997). Skala dyrektywności J. J. Raya [J. J. Ray’s Directiveness Scale]. Pracownia Testów Psychologicznych Polskiego Towarzystwa Psychologicznego.

Bugental, D. B., \& Lewis, J. C. (1999). The paradoxical misuse of power by those who see themselves as powerless: How does it happen? Journal of Social Issues, 55(1), 51-64. https://doi.org/10.1111/0022-4537.00104

Cable, D. M., \& Judge, T. A. (2003). Managers' upward influence tactic strategies: The role of manager personality and supervisor leadership style. Journal of Organizational Behavior, 24(2), 197-214. https://doi.org/10.1002/job.183 
Caldwell, D. F., \& Burger, J. M. (1997). Personality and social influence strategies in the Workplace. Personality and Social Psychology Bulletin, 23(10), 1003-1012. https://doi.org/ 10.1177/01461672972310001

Case, T., Dosier, L., Murkison, G., \& Keys, B. (1988). How managers influence superiors: A study of upward influence tactics. Leadership \& Organization Development Journal, 9(4), 25-31. doi:10.1108/eb053641

Celińska-Nieckarz, S., Nieckarz, Z., \& Konieczny, T. K. (2012). An evaluation of the effectiveness of middle managers and their degree of directivity. In M. Lipowski \& Z. Nieckarz (Eds.), Empirical aspects of the psychology of management/ Empiryczne oblicza psychologii zarządzania (pp. 98-131). Wyższa Szkoła Administracji i Biznesu im. Eugeniusza Kwiatkowskiego w Gdyni.

Chemers, M. M. (2000). Leadership research and theory: A functional integration. Group Dynamics: Theory, Research, and Practice, 4(1), 27-43. https://doi.org/10.1037/10892699.4.1.27

Cieciuch, J., \& Łaguna, M. (2014). Wielka Piątka i nie tylko. Cechy osobowości i ich pomiar [The Big Five and beyond: Personality traits and their measurement]. Roczniki Psychologiczne, 17(2), 239-247.

Cislak, A., Cichocka, A., Wojcik, A. D., \& Frankowska, N. (2018). Power corrupts, but control does not: What stands behind the effects of holding high positions. Personality and Social Psychology Bulletin, 44(6), 944-957.

Costa, P. T., \& McCrae, R. R. (1992). Normal personality assessment in clinical practice: The NEO Personality Inventory. Psychological Assessment, 4(1), 5-13.

Czerniawska, M. (2018). Directiveness and attitudes toward entrepreneurship. 10th International Scientific Conference "Business and Management 2018," May 3-4, 2018, Vilnius, Lithuania.

de Raad, B. (1998). Five big, Big Five issues: Rationale, content, structure, status, and crosscultural assessment. European Psychologist, 3, 113-124.

Doliński, D. (2011). Techniki wptywu społecznego [Social influence techniques]. Scholar.

Duckitt, J. H. (1983). Directiveness and authoritarianism: Some research findings and a critical reappraisal. South African Journal of Psychology, 13(1), 10-12.

Emans, B. J., Munduate, L., Klaver, E., \& Van de Vliert, E. (2003). Constructive consequences of leaders' forcing influence styles. Applied Psychology, 52(1), 36-54.

Faeth, M. A. (2004). Power, authority and influence: A comparative study of the behavioral influence tactics used by lay and ordained leaders in the episcopal church (Doctoral dissertation, Virginia Polytechnic Institute and State University, Falls Church, VA). Retrieved March 13, 2020 from https://vtechworks.lib.vt.edu/bitstream/handle/10919/27045/mabfa ethdiss.pdf?sequence $=1 \&$ isAllowed $=\mathrm{y}$

Falbe, C. M., \& Yukl, G. (1992). Consequences for managers of using single influence tactics and combinations of tactics. Academy of Management Journal, 35(3), 638-652.

Ferris, G. R., Treadway, D. C., Kolodinsky, R. W., Hochwarter, W. A., Kacmar, C. J., Douglas, C., \& Frink, D. D. (2005). Development and validation of the political skill inventory. Journal of Management, 31(1), 126-152.

French, J. R. P., Jr., \& Raven, B. (1959). The bases of social power. In D. Cartwright (Ed.), Studies in social power (pp. 150-167). University of Michigan.

Gonçalves, M. (2013). Leadership styles: The power to influence others. International Journal of Business and Social Science, 4(4), 1-3. 
Goodstadt, B. E., \& Hjelle, L. A. (1973). Power to the powerless: locus of control and the use of power. Journal of Personality and Social Psychology, 27(2), 190-196.

Gorbaniuk, O., Korczak, A., Toruj, N., Czarnejko, A., Macheta, K., Jałoszewska, M., CharęzińskaNowocień, M., Karpiński, R., Garwoliński, Ł., Misiuro, T., Zygnerska, M., Bojan, I., Rykowska, K., Wawrzaszek, P., Jeliński, J., \& Hawryluk, M. (2019). Comprehensive psycholexical classification of Polish person-descriptive terms. Current Issues in Personality Psychology, 7(2), 142-154. https://doi.org/10.5114/cipp.2019.82792

Hryniewicz, J. T. (2007). Stosunki pracy w polskich organizacjach [Employment relationships in Polish organizations]. Scholar.

Jasiński, T., \& Wilczyńska, D. (2015). Directiveness and self-esteem, and system of values in the students of physical education. International Journal of Health, Physical Education and Computer Science in Sports, 20(1), 90-95.

John, O. P., \& Srivastava, S. (1999). The Big Five trait taxonomy: History, measurement, and theoretical perspectives. In O. P. John, R. W. Robins, \& L. A. Pervin (Eds.), Handbook of personality: Theory and research (pp. 114-158). Guilford Press.

Judge, T. A., Bono, J. E., Ilies, R., \& Gerhardt, M. W. (2002). Personality and leadership: a qualitative and quantitative review. Journal of Applied psychology, 87(4), 765-780, https://doi.org/10.1037//0021-9010.87.4.765

Judge, T. A., Heller, D., \& Mount, M. K. (2002). Five-factor model of personality and job satisfaction: A meta-analysis. Journal of Applied Psychology, 87(3), 530-541.

Judge, T. A., Higgins, C. A., Thoresen, C. J., \& Barrick, M. R. (1999). The big five personality traits, general mental ability, and career success across the life span. Personnel Psychology, $52(3), 621-652$.

Judge, T. A., Klinger, R., Simon, L. S., \& Yang, I. W. F. (2008). The contributions of personality to organizational behavior and psychology: Findings, criticisms, and future research directions. Social and Personality Psychology Compass, 2(5), 1982-2000.

Kennedy, J. C., Fu, P. P., \& Yukl, G. (2003). Influence tactics across twelve cultures. In W. H. Mobley, P. W. Dortan, Advances in global leadership (Vol. 3, pp. 127-147). Emerald Group Publishing. Retrieved October 16, 2019, from https://www.researchgate.net/profile/ Jeffrey_Kennedy2/publication/235311531_INFLUENCE_TACTICS_ACROSS_TWELVE CULTURES/links/5bf46d8d4585150b2bc4af23/INFLUENCE-TACTICS-ACROSS-TWEL VE-CULTURES.pdf

Kipnis, D., Schmidt, S. M., \& Wilkinson, I. (1980). Intraorganizational influence tactics: Explorations in getting one's way. Journal of Applied Psychology, 65(4), 440-452.

Kocur, D. (2017). The need for power and influence, sense of power and directiveness among teachers. The New Educational Review, 48(2), 257-267. https://doi.org/10.15804/tner. 2017.48.2.21

Kożusznik, B. (2005). Wpływ społeczny $w$ organizacji [Social influence in an organization]. Polskie Wydawnictwo Ekonomiczne.

Kożusznik, B., Paliga, M., Smorczewska, B., Grabowski, D., \& Kożusznik, M. W. (2018). Development and validation of the Team Influence Relations Scale (TIReS): Beyond the measurement of individual influence in teams. Baltic Journal of Management, 13(1), 84-103.

Kożusznik, B., Pollak, A., Adamek, D., \& Grabowski, D. (2015). Development and validation of the Influence Regulation and Deinfluentization Scale (DEI-beh). Polish Journal of Applied Psychology, 13(4), 91-108. 
Magee, J. C., \& Galinsky, A. D. (2008). Social hierarchy: The self-reinforcing nature of power and status. Academy of Management Annals, 2(1), 351-398. https://doi.org/10.5465/19416520802 211628

Mączyński, J., Jago, A., Reber, G., \& Böhnisch, W. (1993). Styl kierowania ludźmi polskich, austriackich i amerykańskich menedżerów. Przegląd Psychologiczny, 1, 65-80.

McClelland, D. C., \& Boyatzis, R. E. (1982). Leadership motive pattern and long-term success in management. Journal of Applied Psychology, 67(6), 737-743.

Mowday, R. T. (1978). The exercise of upward influence in organizations. Administrative Science Quarterly, 137-156.

Paliga, M., \& Pollak, A. (2016). Różnice pokoleniowe w sposobach wywierania wpływu społecznego u kadry kierowniczej. Społeczeństwo i Edukacja, 2(21), 149-165.

Overbeck, J. R., Neale, M. A., \& Govan, C. L. (2010). I feel, therefore you act: Intrapersonal and interpersonal effects of emotion on negotiation as a function of social power. Organizational Behavior and Human Decision Processes, 112(2), 126-139. https://doi.org/10.1016/j.obhdp. 2010.02.004

Porter, L. W., Angle, H. L., \& Allen, R. W. (2003). Influence, power, and politics in organizational settings. In L. W. Porter, H. L. Angle, \& R. W. Allen (Eds.), Organizational influence processes (2nd ed., pp. 3-13). M. E. Sharpe.

Raven, B. H., \& Kruglanski, A. W. (1970). Conflict and power. In P. Swingle (Ed.), The structure of conflict (pp. 69-109). Academic Press.

Ray, J. J. (1971). Ethnocentrism — attitudes and behaviour. Australian Quarterly, 43(2), 89-97.

Ray, J. J. (1976). Do authoritarians hold authoritarian attitudes? Human Relations, 29(4), 307-325.

Ray, J. J. (1981). Authoritarianism, dominance and assertiveness. Journal of Personality Assessment, 45(4), 390-397.

Santorski, J., \& Michalik, E. (2016). Polska na kozetce [Poland on the couch]. Burda Publishing Polska.

Saucier, G., \& Srivastava, S. (2015). What makes a good structural model of personality? Evaluating the Big Five and alternatives. In M. Mikulincer \& P. R. Shaver (Eds.), APA handbook of personality and social psychology: Vol. 4. Personality Processes and Individual Differences (pp. 283-305). Cambridge University Press.

Singh, A. (2009). Organizational power in perspective. Leadership and Management in Engineering, 9(4), 165-176. https://doi.org/10.1061/(asce)lm.1943-5630.0000018

Spengler, M., Damian, R. I., \& Roberts, B. W. (2018). How you behave in school predicts life success above and beyond family background, broad traits, and cognitive ability. Journal of Personality and Social Psychology, 114(4), 620-636.

Thibaut, J., \& Kelley, H. H. (1959). The Social Psychology of Groups. Wiley.

Trinkle, B., \& Lam, M. (2014). Construct validity of organizational appeal: A newly identified influence tactic to elicit professional accountants' task commitment. Advances in Accounting Behavioral Research, 17, 183-211.

Turner, J. C. (2005). Explaining the nature of power: A three-process theory. European Journal of Social Psychology, 35(1), 1-22. https://doi.org/10.1002/ejsp.244

Turska-Kawa, A., \& Wojtasik, W. (2017). "Directiveness" as a predictor of religious attitudes. Polish Sociological Review, 2(198), 189-201. 
Yang, C., Liu, Y., \& Chen, H. (2018). The influence of power sense on cooperation: The mediating effect of perceived control and the moderating effect of dominance motivation. Psychology, 9, $1065-1080$.

Yukl, G. (2010). Leadership in organizations (7th ed.). Pearson.

Yukl, G., \& Falbe, C. M. (1990). Influence tactics and objectives in upward, downward, and lateral influence attempts. Journal of Applied Psychology, 75, 132-140.

Yukl, G., \& Seifert, C. (2002). Preliminary validation of an extended version of the Influence Behavior Questionnaire. Paper presented at the Society for Industrial-Organizational Psychology meetings, Toronto, Canada.

Yukl, G., \& Tracey, J. B. (2003). Consequences of influence tactics used with subordinates, peers, and the boss. In L. W. Porter, H. L. Angle, \& R. W. Allen (Eds.), Organizational influence processes (2nd ed., pp. 96-116). M. E. Sharpe.

Yukl, G., Chavez, C., \& Seifert, C. F. (2005). Assessing the construct validity and utility of two new influence tactics. Journal of Organizational Behavior: The International Journal of Industrial, Occupational and Organizational Psychology and Behavior, 26(6), 705-725.

Zawadzki, B., Strelau, J., Szczepaniak, P., \& Śliwińska, M. (1998). Inwentarz osobowości NEOFFI Costy i McCrae. Adaptacja polska. Podręcznik [Personality Inventory NEO-FFI by Costa and McCrae: Polish adaptation: A manual]. Pracownia Testów Psychologicznych Polskiego Towarzystwa Psychologicznego. 